\title{
ЄВРОПЕЙСЬКИЙ ФРОНТИР І ПРОБЛЕМИ ПОЧАТКІВ КОЗАЦТВА
}

\author{
Леонтій ВОЙТОВИЧ \\ Львівський національний університет імені Івана Франка \\ Кафедра історії середніх віків та візантиністики \\ вул. Університетська 1, 79000, Львів, Україна \\ e-mail: lev67420@ukr.net
}

Проблеми початків козацтва і їх формування в рамках европейського фронтиру далі $\epsilon$ актуальними. Повільно долаються давні стереотипи, зокрема версія появи козацтва в результаті трансформації селян-втікачів від феодального гніту в умовах ординської загрози. Але все ще відроджуються версії уходництва або ж походження козаків від бродників. У пропонованій студії проаналізовано вражливі сторони існуючих версій. Розглянена ситуація у причорноморських степах в період розпаду Золотої Орди і появи Кримського ханства, проблема оборони степових кордонів. Проаналізовано появу на фронтирі ординських козаків, початки і умови формування українського козацтва і його зв'язок з нижчими військовими станами Великого князівства Литовського та участь шляхти і окремих князівсьвих родин у цих процесах. Повністю підтримано версію Сергія Леп'явка стосовно формування українського козацтва. Прослідковано зміну чисельности, структуру і організацію, озброєння, логістику козацького війська, причин активности у морських походах.

Окрема увага приділена козацькій еліті, іiї стосункам з адміністрацією, прагненням i сподіванням, спробам організувати реєстрове війська і підпорядкувати козацтво державній владі, зокрема рекомендації київського біскупа Йосифа Верещинського. Показано, що уряд не вникав у ситуацію фронтиру, навіть намагався ліквідувати козацтво, не маючи йому відповідної альтернативи. При цьому під час кожного загострення на різних кордонах, зокрема у Прибалтиці чи на сході з Московською державою, уряд розгортав мобілізацію козацтва, відкладаючи на майбутнє вирішувати пов'язані з ним проблеми. Врешті ця невдала політика уряду підштовхнула козацтво до епохи польсько-козацьких війн, які підготували падіння самої Речі Посполитої.

Ключові слова: европейський фронтир, козацтво, Дике поле, бродники, низове військо, Йосиф Верещинський.

Европейський фронтир ${ }^{1}$, своєрідна “сторона кордону як явища, що легко могло перетворитися у справжній військовий фронт”2, тобто мілітарна зона, яка відділяла європейську християнську цивілізацію від кочових суспільств, пролягала причорноморськими степами від кінця IX ст., коли християнство нарешті утвердилося на Русі. Поява могутньої Монгольської імперії і їі Західного

\footnotetext{
${ }^{1}$ Ігор Чорновол. Теорія компаративних фронтирів. Регіональна історія Украӥни. Вип. 3. (Київ, 2009), 41-66; Його ж. Відповідники поняття frontier у інших мовах. Historia - Mentalnoњж Tö̈sатоњж. Rosja i Europa Zachodnia w polskiej i ukraicskiej historiografii XIX i XX wieku. (Gdacsk: Wydawnictwo Uniwersytetu Gdacskiego, 2013), 125-140; Його ж. Компаративні фронтири. Світовий і вітчизняний вимір. (Київ: Критика, 2015). 376 с.

${ }^{2}$ Ярослав Дашкевич. Україна на Великому кордоні. Давня і середньовічна історія Украйни. На пошану Іона Винокура з нагоди його 70-річчя. (Кам’янець-Подільський, 2000), 290.
} 
ISSN 2078-6077. Наукові зошити історичного факультету Львівського університету. 2020. Випуск 21. Proceedings of History Faculty of Lviv University. 2020. Issue 21.

відламу - Золотої Орди відсунуло європейський фронтир до меж королівства Pуси (Галицько-Волинської держави), чиє військо в XIV ст. сусіди вважали нездоланним захистом від ординців ${ }^{3}$. Розпад Золотої Орди і перехід причорноморських степів до Великого князівства Литовського, знову пересунули европейський фронтир далі на південь. Поява окремого Кримського ханства, яке підштовхували одне проти другого Велике князівство Московське та Велике князівство Литовське, які перебували у постійній конфронтації, покликоло проблему оборони південних кордонів ${ }^{4}$.

Система оборони південних кордонів обох держав бажала крашого, що значно полегшувало ординцям їх завдання. Московська держава щоліта (зимою Дике поле було непрохідне) виряджала в поле спеціяльний наряд - до 20 тис. помісного війська, яке татари легко обходили, користуючись неузгодженістю дій окремих командирів і слабкою мобільністю противника 5 . Борис Годунов (1551-23.04.1605) розпочав колонізацію південних степів, просуваючи далі на південь лінії оборони, укріплені засіками, розвідувальними заставами та фортецями, удосконалюючи службу в нарядах. Його наступники продовжили цю практику. Але ефективність тієї організації оборони була низька ${ }^{6}$. У Польсько-Литовської держави взагалі не було жодної системи оборони південних кордонів крім ріденького ланцюжка застарілих замків зі залогами у кілька десятків воїнів, підсилених ополченцями міст та містечок. Тому в 1482 р. Менглі-Гірей легко дійшов аж до Києва і без особливих зусиль навіть здобув його, бо укріплення Києва від домонгольських часів тільки трохи підремонтували київські Гедиміновичі. Так само виглядали укріплення інших нових і старих міст ${ }^{7}$. Прикордонні старости не мали ні сил ні

\footnotetext{
3 Лист польського короля Владислава Локєтка до папи Івана XXII від 21.05.1323 p. (Monumenta Poloniae Vaticana. T. 1. (Krakyw, 1913), 83).

${ }^{4}$ Богдан Якимович. Феномен нашої історії. До 500-річчя українського козацтва. Україна та українці: подї далекі і близькі. (Львів, 2017), 373-374.

5 “Оглядаючись на оборонну систему південного фронту Московської держави в цілому дивуєшся іiі розтягненості, рихлості і, особливо, неузгодженості розвідувальної служби 3 розміщенням московських армій” (Алексей Яковлев. Засечная черта Московського государства в XVII веке: очерк из истории обороны южной окраины Московского государства. (Москва, 1916), 287)

6 “.... до побудови Білгородської лінії достоїнства „московської оборонної системи” були вельми сумнівні і помітні тільки у порівнянні з майже повною відсутністю такої у Польщі... Уряд не піклувався серйозно про оборону повітів польової окраїни, обмежуючись традиційною сторожовою службою, котра поступово втрачала загальноросійські організаційні форми i значення" (Владимир Загоровский. Белгородская черта. (Воронеж, 1969), 54, 69). Воєначальники, призначені керувати обороною від Кримського ханства, проявляли “малодушність, нерішучість і непридатність”, а “розпорядження московського уряду... були випадковими, викликаними тимчасовими обставинами і не мали зв'язку одне з одним” (Русская военная сила. История развития военного дела от начала Руси до настоящего времени. Под ред. А. Н. Петрова. Т. 1. Изд. 2. (Москва, 1897), 118, 245).

${ }^{7}$ У Каневі новий замок на Дніпровій горі, оточеній ровом, займав прямокутник $80 * 40$ метрів, стіни якого, як і в часи Київської Русі, були зроблені з 26 городнів (дерев' яних зрубів шириною до 6 метрів, заповнених утрамбованою землею і обмазаних назовні глиною для охорони від
} 
коштів для організації хоча б сторожової служби. А важкі панцерні дружини удільних українських князів не мали жодних шансів догнати ординців, які вміло уникали 3 ними зіткнень. Непридатність шляхетського ополчення повністю проявилась у виправах в Дике поле, зокрема в $1497 \mathrm{p} .{ }^{8}$, а сумна статистика ординських нападів та іiі резонанс у суспільстві ${ }^{9}$ змушували шукати виходу у виплатах “упоминків” та спробах домовитися або вплинути на Гіреїв через їх сюзеренів Османів, що постійно завершувалося невдачами ${ }^{10}$.

I за таких умов фронтир народив спецефічне явище, яке використали обидва супротивники - козацтво.

Степові простори Дешт-і Кипчаку (Дикого поля) були багаті звіриною та птицями, а численні ріки - рибою та бобрами. Крім того тут добували селітру (одну з головних складових пороху) та на численних солончаках сіль (основний консервант цієї епохи). Однак саме перебування в Дикому полі вимагало досконалого володіння зброєю і наявності такої зброї, що була дуже дорогою, а від права володіти зброєю практично виключено селянство, яке відлучили від зброї ще в ранньому середньовіччі. І це дозволяє повністю відкинути заідеологізовані стереотипи про селян-втікачів від феодального гніту, які стали козаками ${ }^{11} .3$ цієї ж причини дуже обережно слід ставитися і до досі популярної

вогню). На стінах було 6 критих веж, помости і припілки. Єдині ворота мали підвісний міст через рів. У середині замку були дерев'яні церква, дім старости, погреби, кілька маленьких приміщень для челяді та залоги. Вся артилерія замку і його вогнепальна зброя числили 1 велику, 2 малі гармати, 3 серпантини калібром 11 см, 3 гаківниці та 20 аркебуз (Архив Юго-Западной России. Ч. 7. Т. 1. Док. 15. (Киев, 1887), 91-105). Місто, яке примикало до замку, оточував палісад на земляних валах і крім ополчення, очоленого війтом, не мало жодного війська.

${ }^{8}$ Olgierd Górka. Białogród i Kilia a wyprawa 1497 r. (Warszawa, 1932); Zigmund Spieralski. Obrona potoczna. Pamiętnik VIII Powszechnego Zjazdu Historyków Polskich w Krakowie 14-17 wrzeœnia 1958. (Warszawa, 1958), 241-249.

9 Ярослав Дзира. Татаро-турецькі напади на Україну XIII-XVI ст. за хроніками Бельського та Стрийковського. Украӥнський історико-географічний збірник. Вип. 1. (Київ, 1971), 90-124.

${ }^{10}$ Кримські правителі вічно скаржилися на невчасно прислані “упоминки” та підступність сусідів, а часом звалювали на вину свавільних васалів з ногайських орд. У 1607 р. ординці взяли великий ясир в околицях Вінниці, Гайсина і Шаргорода, король Сігізмунд ІІІ звернувся 8 листопада до султана Ахмеда I, з яким у нього був мир. Поки скарга розглядалася і ординці доповідали про страхітливі напади запорозьких козаків, у 1608 р. татарські загони знову стояли під Гайсином, біля Прилук, Немирова і Вінниці (Леонид Львов. Отношения между Запорожской Сечью и Крымом. (Одесса, 1895); Владислав Хензель. Проблема ясыря в польско-турецких отношениях XVI-XVII вв. Россия, Польша и Причерноморье в XV-XVIII вв. (Москва, 1979), 147-158; Тарас Батюк. Збройні сили України в протистоянні турецько-татарській експансії у другій половині XVI - на початку XVII ст.: історіографія проблеми. Дрогобицький краєзнавчий збірник. Вип. 10. (Дрогобич, 2006), 186-200).

${ }^{11}$ Для селян, які жили у відносній безпеці і не відчували такого гноблення, яке би змусило їх кидати родини і наражати себе на смертельну небезпеку в Дикому полі без зброї, придбати яку було неможливо без відповідних ресурсів і без навиків володіння цією зброєю та елементами військової організації, не існувало чинників, які би могли спонукати до подібних дій. Навіть право селянського відходу з землі власника було обмежене у Московській державі тільки у Судебнику 1497 р., у Польщі - у 1505 р., в Литві - у 1588 р. Протягом XV ст. панщина (labores) 
ISSN 2078-6077. Наукові зошити історичного факультету Львівського університету. 2020. Випуск 21. Proceedings of History Faculty of Lviv University. 2020. Issue 21.

теорії уходництва $a^{12}$. Важко собі уявити сезонних пасічників чи, навіть, мисливців відповідно озброєних і у панцирах, без чого в XV ст., як і без належної військової оргазізації, вижити в Дикому полі було би неможливо.

Також не виглядає переконливим відродження інтересу до версії походження козаків від бродників ${ }^{13}$, які були окремим етносом, близьким до аланів ${ }^{14}$, або ж корпорацією, яка обслуговувала броди і торговельні шляхи в низів'ях Дунаю, Дністра, Південного Бугу та Дніпра ${ }^{15}$. Востаннє бродники згадані під 1353 р. у складі війська великого князя рязанського Олега Івановича на війні з Москвою ${ }^{16}$. Зрозуміло, що ці бродники ніяк не могли бути пов'язані з нащадками бродників, які наприкінці ХІІ ст. допомагали болгарам проти візантійців. Існування подібної

складала в середньому 14 днів на рік, пізніше зросла до 1 дня на тиждень (постанова Торуньського сейму 1519 р.) і королівська влада забороняла цю норму збільшувати (1533). Тільки від $1570-\mathrm{x}$ pp. ця норма почала зростати до 2 днів на тиждень 3 лану землі (лан або з 1557 р. волока - бл. 18 га землі, яка надавалася патріярхальній родині з 10-12 осіб). При цьому села на німецькому і волоському праві не відбували панщини зовсім. Прикордонні села часто відбували сторожову повинність і т. д. Поява фільварків, де частково використовували найману працю, та ріст попиту на сільськогосподарську продукцію, яку вивозили в Европу, викликали не тільки економічний підйом Речі Посполитої у XV ст., але й зростання доходів сільського населення (Михайло Грушевський. Історія Украӥни-Руси. Т. 5. (Львів, 1905), 107-222; Т. 6. (Львів, 1907), 141-234).

${ }^{12}$ Василь Боєчко, Анатолій Чабан. Роль зарубіжних територій в процесі генезису козацтва. Украӥнський історичний журнал. (Київ, 1999), № 2, 48-63.

${ }^{13}$ Матвей Любавский. Начальная история малорусского казачества. Журнал Министерства Народного Образования. (1885), № 7, 12; Николай Волынкин. Предшественники казачества бродники. Вестник Московского гос. ун-та. Серия 8. История. (Москва, 1949), 56; Микола Котляр. Хто такі бродники (До проблеми виникнення українського козацтва. Украӥнський історичний журнал. (1969), № 5, 95-101; Георгий Губарев. Казаки и их земля в свете новых данных. Вторая книга о казаках. (Буэнос-Айрес, 1974), 11; Андрей Гордеев. История казачества. Т. 1. (Москва, 1992), 73-74; Александр Сопов. Историография вопроса о происхождении казачества. Проблемы изучения и пропаганды казачьей культуры. (Майкоп, 1998), 20-28; Его же. Исторические предшественники казаков, становление и развитие казачества. Вестник Адыгейского гос. ун-та. (2006), № 1, 27-32; Его же. Бродники - предшественники казаков. Bопросы казачьей истории и культуры. Вып. 4. (Майкоп, 2009), 16-22; Его же. Происхождение казачества: возвращаясь к проблеме. Вестник Московского гос. ун-та. Серия 8. История. (Москва, 2011), № 1, 54-65.

${ }^{14}$ Олег Бубенок. Ясы и бродники в степях Восточной Европы (VI - начало XIII в.). (Киев, 1997), 137.

15 Леонтій Войтович. Галицьке князівство на Нижньому Дунаї. Галич $і$ Галицька земля в державотворчих процесах Украйни. (Галич, 2008), 3-18; Його ж. Галицька земля і Візантія у XIXIV століттях. Дрогобицький краєзнавчий збірник. Вип. 14-15. (Дрогобич, 2011), 37-60; Idem. Ruś halicka a Bizancjum w XI--XIV w.: wybrane problemy. Zeszyte Naukowe Uniwersytetu Jagietłońskiego. Prace Historyczne. T. 138. (Kraków, 2011), 41-64; Idem. Galician Ruthenia and Byzantium in 11-13th century: selected issues. Colloquia Rusica. T. 1. Ruś średniowieczna a sąsiedzi (IX - połowa XIII wieku). (Kraków, 2011), 137-140; Його ж. Галич у політичному житті Європи XI-XIV століть. (Львів, 2015), 105-106; Його ж. Ярослав Осмомисл: спроба портрета. Україна: культурна спадщина, національна свідомість, державність. Вип. 28. Іван Крип'якевич у родинній традиції, науці, суспільстві. (Львів, 2016), 468-481.

${ }^{16}$ Рогожский летописец. Полное собрание русских летописей. Т. 15. Вып. 1. (Санкт-Петербург, 1922), 63. 
корпорації в XIV ст. у причорноморських степах між Дніпром і Дунаєм, заповнених великими ординськими містами, більш ніж сумнівно.

Зрозуміло, що першими господарями окраїн Дикого поля були степовикиординці. В ординських улусах на їх межах ближче до осілого населення зосереджувалися нукери та улани, які не хотіли перебувати в системі ординської організації з їі жорстким поділом на десятки та сотні і виконанням наказів мурз та емірів. Такі ординці не лише полювали та рибалили в прикордонній зоні, а на свій страх та ризик організовували наскоки на осіле населення та купецькі каравани, збуваючи свою здобич в ординських ставках та містах на ринках. Звалися такі розбійники - козаками ${ }^{17}$. Ординська верхівка часто переслідувала козаків, але переважно не заваджала їх існуванню, а при потребі використовувала як провідників під час походів, а купці з охотою скупали їх здобич по дешевій ціні, взамін продаючи по дорогій ціні необхідні припаси та харчі. На зиму ці козаки приставали до ординських зимівників, проїдаючи тут свої ресурси, щоби влітку знову відійти в степ. Подібні степові “промисловики” стали організовуватися у ватаги і на степових окраїнах українських та російських князівств. Серед них значну частину складали звиклі до степу рештки половиів та чорних клобуків, які раніше були пов'язані з руськими князями. Ці неординські козаки теж дозволяли собі шарпати купецькі каравани, а також ординські стани. На зиму вони відходили у прикордонні міста, збуваючи свою здобич та результати “промислів". Адміністрація прикордонних земель користала 3 їх досвіду та допомоги і не заваджала їх діяльності. Під їх прикриттям, напевно, діяли найвідчайдушніші уходники.

Зачатки їх організації припадають десь на 1393-1411 рр., коли васал великого князя литовського Вітовта внук Мамая князь Олександр (Лексада) Глинський на степових кордонах нижче порогів почав формувати 3 козаків різного походження за орденськими зразками низове військо ${ }^{18}$. Трохи пізніше такі козаки зафіксовані під 1444 р. у Рязанському князівстві, де вони взяли участь у боях 3 казанським царевичем Мустафою, на лижах, будучи озброєні сулицями, рогатинами і шаблями ${ }^{19}$. Перші українські козаки, згадуються в 1489 р. як

${ }^{17}$ Тюркське слово козак у значенні вільна людина має дуже давнє походження (Григорій Халимоненко. Інститут козацтва: тюркського й українського. Східний світ. (1993), № 1, 108111). Вперше воно зафіксоване у Codex Cumanicus (словнику половецької мови, список якого 3 1303 р. зберігся в бібліотеці собору св. Марка у Венеціі), складеному латинськими місіонерами XII-XIII ст., а пізніше зустрічається в актах генуезьких колоній у Криму. Етимологія цієї назви спірна. Тюркське ко - броня, паниир, а закінгі-сторож межі, від заха - межа. Можливо, що первинне значення терміну козак - опанцерований сторож на межі (Пётр Бутков. Об имени казак. Вестник Европы. (Москва, 1822), 193).

${ }^{18}$ Вадим Ільїнський, Георгій Шаповалов. Земельно-майновий стан на Запоріжжі у XIV-XV ст. як чинник заснування козацького війська низового. Музейний вісник. Вип. 15/2. (Запоріжжя, 2015), 100-114.

${ }^{19}$ Никоновская летопись. Ч. 3. Полное собрание русских летописей. Т. 11. (Санкт-Петербург, 1897), 62; Николай Арцибашев. Повествование о России. Кн. 3. (Москва, 1843), 194; Михайло Грушевський. Історія Украӥни-Руси. Т. 7. (Київ-Львів, 1909), 78. 
ISSN 2078-6077. Наукові зошити історичного факультету Львівського університету. 2020. Випуск 21. Proceedings of History Faculty of Lviv University. 2020. Issue 21.

провідники війська, очоленого принцом Яном Альбрехтом, сином короля Казимира Ягелончика, які добре знали степ ${ }^{20}$. А у 1492 р. для захисту від козаків кримський хан Менглі-Гірей відбудував стару литовську фортецю Дашків як Очаків і спорудув біля о. Тавані (поблизу нинішньої Каховки), де ширина ріки не перевищувала 500 кроків, фортецю Іслам-Кермень ${ }^{21}$.

Тому, на мій погляд, слід погодитися з обгрунтованим висновком Сергія Леп'явка, що козацтво виникло на базі різноманітних нижчих військових станів Великого князівства Литовського, які не мали земельних володінь і власних гербів: панцирних і путних бояр, замкових слуг та інших ${ }^{22}$. Вони злилися 3 нащадками козаків князя Олександра Глинського, від яких перебрали ряд тюрських назв, термінів і звичок. До них приєдналася також дрібна шляхта i, навіть, нащадки удільних князів ${ }^{23}$. Переважна більшість козацьких вождів походила 3 шляхти, менше 3 міщан $^{24}$. 3 середини XVI ст. в козацькому середовищі

${ }^{20}$ Польський хроніст Мартин Бєльський (1495-1575) писав, що військо успішно просувалося у степах Південного Поділля завдяки місцевим козакам, які були провідниками (Kronika Marcina Bielskiego. T. 2. (Sanok, 1856), 882).

${ }^{21}$ Алексей Гайворонский. Созвездие Гераев. (Симферополь, 2003), 15-16; Его же. Повелители двух материков. Т. 1. (Киев-Бахчисарай, 2007), 40-101; Владислав Гулевич. Казимир Ягайлович і Менглі Гірей; від друзів до ворогів. Украӥнський історичний журнал. (Київ, 2013), № 1(508), 40-66.

22 Зближення обох частин Речі Посполитої та панівна ідеологія сарматського міту все більше перекладали військову службу винятково на шляхетство. Уряд Великого князівства Литовського розпочав ревізію і перевірку земельних надань та шляхетства (вивід прав шляхетства 1522 , опис війська 1528 р., ревізії замків 1545 та 1552 рр., волочна поміра 1557 р.). Ті категорії бояр, які не змогли довести свого шляхетства, переходили в корпорацію державних селян і мусили платити податки. Люблінська унія 1569 р. поширила на українські землі взамін Литовських статутів польське право, яке взагалі не знало негербової шляхти. "Бояри-шляхта" мусили перетворитися на підданих і змінити шаблю на рало. Частка 3 них збереглася як “околична шляхта" біля прикордонних замків типу Бару, де їх підтримала місцева адміністрація як єдиний засіб оборони території, чи як пізніша “ходачкова шляхта" на карпатських кордонах (також за мовчазною згодою місцевої адміністрації). Більшість, особливо на Київщині та Брацлавщині, влилася у лави козацтва, принісши з собою до нього лицарські традиції епохи Ягеллонів (Сергій Леп'явко. Про природу станових привілеїв українського козацтва. Проблеми украӥнської медієвістики. (Київ, 1990), 8998; Його ж. До проблем становлення козацького стану. Другий Міжнародний конгрес украӥністів. Львів, 23-28 серпня 1993 р. Доповіді і повідомлення. Історія. Ч. 1. (Львів, 1993), 84-86; Віталій Щербак. Формування козаиького стану в Украйні. (Київ, 1997).

${ }^{23}$ Передовсім Вишневецькі та Ружинські. Князь Флоріян Гедройц був старшиною у війську Северина Наливайка, залишився серед козаків і пізніше з Федором Полоусом воював проти урядових військ (Володимир Доманицький. Козачизна на переломі XVI і XVII століть (1591-1603). Записки НТШ. Т. 63. (Львів, 1905), 134). Князь Януш Богданович Друцький-Соколинський у 1615 р. перебував серед запорожців і був ініціятором походу до Очакова (Документи російських архівів з історії Украӥни. Т. 1. Документи до історії запорозького козацтва 1613-1620 рр. Упорядники Л. Войтович, Л. Заборовський, Я. Ісаєвич, Ф. Сисин, А. Турилов, Б. Флоря. (Львів, 1998), 83).

${ }^{24}$ Козацькі вожді: Пац Юрій (1489-1500), Лянцкоронський Предислав (1503-1531), отаман Полюс (1508), Полозович Сенко $(1508,1511,1524)$, Дашкович Остафій (1508-1535), отаман Венжик з Хмільника (1514), Кмітіч Христофор (1520, 1524), Претвіч Якуб Бернард (15381551), князь Вишневецький-Байда Дмитро (1551-1563), отаман Млинський (1563-1570), отаман Бируля (1566-1570), отаман Іскорка (1566-1570), регіментар реєстру Бадовський Ян (5.06.1572- 
ISSN 2078-6077. Наукові зошити історичного факультету Львівського університету. 2020. Випуск 21. Proceedings of History Faculty of Lviv University. 2020. Issue 21.

1581), гетьман Свірговський Іван (1574), кошовий отаман Павлюк (1575), гетьман князь Богдан Ружинський (1575-1576), гетьман Шах Яків (1577-1578), гетьман Лук'ян Чорнинський (1578, 1586), гетьман Арковський (1578), гетьман Дем’ян Скалозуб (1579-1580), князь Ружинський Остафій (1581-1583), гетьман Орешовський Ян (1581-1590), кошовий отаман Зборовський Самійло (1583-1584), гетьман князь Ружинський Михайло (1584-1586), кошовий отаман Кулага Захар (1585), гетьман Богдан Микошинський $(1586,1594,1595)$, князь Ружинський Микола (1587), князь Ружинський Кирик (1588), гетьман Чановицький Войтех (1590), гетьман Косинський Криштоф (1590-1593), гетьман Полоус Федір (весна 1595,1596,1598), гетьман Лобода Григорій (весна 1595 - 20.03.1596), гетьман Шаула Матвій (20.03-24.03.1596), гетьман Наливайко Северин (Семерій?) (24.03-28.05.1596), регіментар реєстру Байбуза Тихон (1596-1599), гетьман Кремпський Кароль (літо 1596), гетьман Нечковський Христофор (літо 1596), гетьман Кішка Самійло (1599-1602), гетьман Крутневич (Кортневич) Гаврило (1602-1603), гетьман Куцко (Куцкович) Іван (1602-1603), гетьман Косий Іван (1602-1603), гетьман Ізапович Григорій (кінець 1606), гетьман Зборовський $(1606,1608)$, гетьман Олевченко (1609), гетьман Андрієвич Каленик (1609-1610, 10.1624-01.1625, літо 1632), гетьман Тискіневич Григорій (травень 1610), гетьман Конашевич-Сагайдачний Петро $(1610 ?-03.1617,10.1617-03.1620,08.1621-10.04 .1622)$, гетьман Василь Стрілковський (1616), гетьман Барабаш Дмитро Богданович (03-10.1617), гетьман Стецик (Стецько) (1618), гетьман Неродич-Бородавка Яків (03-23.08.1620), гетьман Голуб Оліфер Євстахович (03.1622-10.1624, перша половина 1626), гетьман Пирський (01-09.1625), гетьман Жмайло Марко (09-5.11.1625), гетьман Дорошенко Михайло (5.11.1625-12.1628, з перервами), гетьман Вовк Костянтин (друга пол. 1626), гетьман Чорний Григорій (12.1628-09.1629), гетьман Іванович Левко (09-12.1629), гетьман Федорович-Трясило Тарас (1630-1632), гетьман Конашевич-Бут Павло (17.05-28.05.1630), гетьман Орендаренко Тиміш Михайлович (28.05.163022.09.1631), гетьман Кулага-Петражицький Іван (22.09.1631-літо 1632), кошовий Бубновський Леонтій (1632), кошовий Перев'язка Семен (1632), гетьман Діденко Андрій Гаврилович (літо 1632-04.1633), гетьман Дорошенко Дорофій (04-8.06.1633), гетьман Острянин (Остряниця) Яків (8.06.1633-1634, 12.1637-3.06.1638), регіментар реєстру Караїмович Ільяш (весна 1634, 24.12.1637-1648), гетьман Сулима Іван (1634-09.1635), гетьман Григорович Максим (осінь 1635), гетьман Михнович-Бут Павло (Павлюк) (1636-24.12.1637), гетьман Томиленко Василь (163608.1637), гетьман Кононович Сава (літо 1637), гетьман Гуня Дмитро (3.06-28.06.1637), кошовий отаман Півтора-Кожуха Карпо (1647), отаман Гулак (Булюк?) Максим (1647), гетьман Хмельницький Богдан Зиновій Михайлович (21.01.1648-27.07.1657), гетьман Забуський Семен (28.07-9.08.1649), гетьман Худолій (02-03.1650), гетьман Хмельницький Юрій Богданович (27.07$24.08 .1657,14.09 .1659-01.1663,1677-1678,1685$, князь Малоросійської України, 1678-1681), гетьман Барабаш Яків (09.1657-05.1658), гетьман Виговський Іван Афанасійович (25.08.165714.09.1659), наказний гетьман Безпалий Іван (10.1658-10.1659), гетьман Іскра Іван Якович (січень 1659), наказний гетьман Сомко Яким (10.1660-06.1663), гетьман Тетеря Павло (01.1663-07.1665), гетьман Брюховецький Іван Максимович (06.1663-8.06.1668), гетьман Опара Степан (07-08.1665), гетьман Дорошнгко Петро Дорофійович (08.1665-19.09.1676), гетьман Суховій Петро (кінець 1668-літо 1669), гетьман Многогрішний Дем’ян (12.1668-05.1672), гетьман Ханенко Михайло (літо 1669- 4.03.1672), гетьман Іван Самойлович (05.1672-07.1687), гетьман Гоголь Остап (05.1675-5.01.1579), гетьман князь Юрій Дука (1681-1683), гетьман Станіслав Куницький (осінь 1683 - зима 1684), гетьман Драгинич Яній (1683-1684), гетьман Могила Андрій (зима 16841686), гетьман Мазепа Іван Степанович (25.07.1687-03.1710), наказний гетьман Гришко (1692), гетьман Петрик (1692-1696), наказний гетьман Самусь (1696-1704), гетьман Скоропадський Іван Ілліч (7.12.1708-14.07.1722), гетьман Орлик Пилип (03.1710-1742), наказний гетьман Полуботок Павло Леонтійович (07.1722-18.12.1723), гетьман Апостол Данило Павлович (1.10.1727-17.01.1734), гетьман Розумовський Кирило Олексійович (1750-1764) (Леонтій Войтович. Османська імперія і Кримське ханство. Фронтир: московсько-литовське суперництво, козацтво, граничари, гайдуки. Войтович Л., Овсінський Ю. Історія війн і військового мистецтва. Т. 1. Від зачатків військової організації до професійних найманих армій. (Харків, 2017), 848-891. 
ISSN 2078-6077. Наукові зошити історичного факультету Львівського університету. 2020. Випуск 21. Proceedings of History Faculty of Lviv University. 2020. Issue 21.

верхівка вже формувалася 3 родовитого козацтва, переплетеного між собою родинними зв'язками ${ }^{25}$.

Перші покоління козаків до часів князя Дмитра Вишневецького-Байди носили дідівське озброєння - легкі захисні панцири, байдани ${ }^{26}$, колонтарі, бехтерці, шоломи. Були озброєні списами, шаблями і луками, які ще використовували до середини XVII ст. Лук був значно ефективніший стосовно густоти стрільби на одній відстані з ручною вогнепальною зброєю, а зі скорострільности перевищував вогнепальну зброю у 5-10 разів ${ }^{27}$. Але козацтво вчасно оцінило ефективність вогнепальної зброї, яка стала основною з другої половини XVI ст. Це були переважно трофейні “яничарки” - турецькі мушкети, на той час значно кращі за европейські ${ }^{28}$. Козацька піхота була знайома зі стрільбою випалами

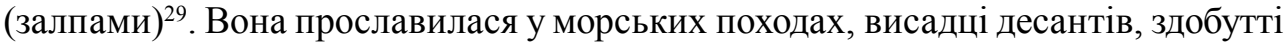
фортець та інших блискавичних операціях. У походах вони використовували весельно-парусний тип кораблів, т. з. “чайки”, які завдяки очеретяному поясу мали високу надійність на воді навіть у штормову погоду ${ }^{30}$. Військо мало польову артилерію $^{31}$ та численну дрібнокаліберну артилерію (фальконети) на чайках і в

${ }^{25}$ Гетьман Криштоф Косинський, вперше згаданий 1586 р. як козацький старшина, був одружений з княжною Марухною Ружинською, дочкою козацького вождя князя Остафія та сестрою гетьманів Богдана (“Чорного гетьмана”), Миколи та Кирика Ружинських (Войтович Л. Князівські династії Східної Свропи (кінець IX-початок XVI cm.). Склад, суспільна і політична роль. (Львів, 2000), 304).

26 Звідки походить прізвисько князя Дмитра Вишневецького - Байда.

${ }^{27}$ Про це навіть свідчить прізвисько знаменитого гетьмана Петра Конашевича Сагайдачний.

${ }^{28}$ Козак 3 мушкетом став символом та емблемою війська (Володимир Грабовецький, Віталій Гавриленко. Невідомий універсал і найдавніша козацька печатка гетьмана Григорія Лободи. Середні віки на Україні. Вип.1. (Київ, 1971), 121-129).

29 При цьому використовувався лад батава в три лави (Дмитро Яворницький. Iсторія запорізьких козаків. Т. 1. (Львів, 1990), 267). Зрозуміло, що при цьому перша лава, зробивши випал, відходила назад, уступаючи місце другій, що дозволяло вести частий, майже неперервний, вогонь. Тобто козацька піхоти використовувала ту саму побудову бойових порядків, що і европейські мушкетери: лад караколь (Леонтій Войтович. Зародження професійного війська. Украӥна: культурна спадщина, національна свідомість, державність. Вип. 21. Scripta manent. Ювілейний збірник на пошану Богдана Якимовича. (Львів, 2012), 164-175; Його ж. Козацька піхота: озброєння, організація, бойові можливості на тлі європейської лінійної піхоти кінця XV середини XVII ст. Проблеми історії країн Центральної та Східної Європи. Збірник наукових праць. Вип. 3. (Кам'янець-Подільський, 2012), 64-79).

${ }^{30}$ Николай Краснов. Казачий флот. Военный сборник. (1885), № 10-12; Віктор Фоменко. Про козацькі човни “чайки” та “дуби” (XVII-XVIII ст.). Украӥнський історичний журнал. (1968), № $8,107-110$. Слід звернути увагу, що Чорне море на той час було турецьким озером, турецький військовий флот перебував у Середземному та Егейському морях, для боротьби з козаками його викликали з допомогою світлового телеграфу або ж кур'єрів, що дозволяло козакам щасливо оминути зустрічі з ним. Таком причорноморські фортеці мали старі споруди і слабкі гарнізони.

3128 травня 1596 р., капітулюючи під Солоницею, козаки видали польному гетьманові Станіславові Жолкєвському 24 гармати, а також срібну гетьманську булаву, срібні литаври та військові хоругви, серед яких було дві хорогви, даровані цісарем Рудольфом II, одна дарована ерцгерцогом Максиміліяном та одна - трансільванським князем Жигмонтом Баторі. 
польових укріпленнях. Козаки були знайомі з мистецтвом інженерної атаки фортець, про що свідчать епізоди 3 московського походу 1618 р., та технікою мінної війни (саме на підкопі від вибуху порохової міни загинув гетьман Богдан Ружинський). Постачання війська було проблематичним, особливо амуніцією. У забезпеченні необхідними військовими матеріялами (селітрою, свинцем, оловом, різними видами зброї) важливу роль відігравали черкаські та канівські старости, а також українські князі та магнати, пов'язані з козацтвом, про що найкраще свідчать регулярні заборони соймів та королівські універсали.

Загальна кількість українських козаків була невеликою і зростала повільно 32 . Черкаський і канівський староста Остап (Євстахій) Дашкович (1455-1535), який 3 допомогою козаків успішно воював з ординцями, у 1532 р. вперше на соймі поставив вимогу про організацію постійного козацького війська для захисту дніпровських перевозів чисельністю 2 тис. піхоти, 500 осіб кінноти та військової флотилії. Але перший козацький реєстр чисельністю 300 осіб організований аж 5 червня 1572 p. ${ }^{33}$. Наступні козацькі реєстри складали: 500 осіб (1578), 1000 (1590, 1617), 2200 (1601), 3000 (1619), 5000 (1624), 6000 (1625, 1630), 7000 (1634), 6000 (1637) і 40 тис. (1649). Реальне число козаків завжди було більшим за реєстри ${ }^{34}$.

32 Перші відомі козацькі походи проти татар у 1489 р. під командуванням київського воєводи Сжі Паца та у 1508 р. під командуванням черкаського старости Сенка Полозовича були кінними. В них рало участь менше тисячі осіб. Той же Сенко Полозович з Христофором Кмітичем у 1523 р. 3 наказу короля Сигізмунда Старого зібрали до двох тисяч козаків з якими обороняли дніпровські переправи, але це військо розійшлося так і не отримавши обіцяної платні (Zbignew Wójcik. Dzikie Pola w ogniu: O kozaczyzni w dawniej Rzeczi Pospolitej. (Warszawa, 1960), 18-20).

33 За універсалом короля Сигізмунда Августа руському воєводі Юрію Язловецькому доручалося набрати “певний почет" чисельністю 300 козаків, який мав очолити подільський шляхтич Ян Бадовський з безпосередным підпорядкуванням коронному гетьманові. Козаки, взяті до реєстру, мали отримувати плату 2-3 польських золотих і сукно на каптан, їм дозволялося тримати у своїх домах вільний шинк (продаж горілки, меду і пива), не платити податків та чиншів. Вони звільнялися з-під юридикції королівських чиновників і підлягали регіментареві реєстру.

${ }^{34}$ у 1574 р. гетьман Іван Свірговський привів в Молдову військо з 1400 козаків, які були організовані у 10 сотень та два загони по дві сотні. У 1577 р. гетьман Яків Шах для походу у Молдову зібрав початково 6 сотень, залишивши три сотні на Січі. Долучивши загони 3 прикордоння він разом з Іваном Підковою вторгнувся в Молдову з 1200 козаками. Враховуючи, що якась частина козаків залишалася на прикордонні, можна оцінити реальну чисельність запорозьких козаків біля 3 тисяч. У 1584 р. кошовий Самійло Зборовський зібрав 3 тисячі нереєстрових козаків. У 1587 р. для наскоку на Кодню гетьман Лук’ян Чорнинський зібрав кілька сотень козаків. У гетьмана Криштофа Косинського під П'яткою 2.02 .1593 р. було 5 тисяч козаків з 26 гарматами. Григорій Лобода у жовтні 1593 р. привів під Київ 4 тисячі козаків. Імперський дипломат досвідчений військовик Еріх Лясота у 1594 р. оцінив сили козаків у 3-5 тисяч. Самі козаки в листі до імператора від 3.07.1594 р. обіцяли виставити 6 тис. У жовтні 1594 р. об’єднані сили Г. Лободи та С. Наливайка осягали 12 тис. За реєстром 1601 р. військо складалося 3 чотирьох 5-сотенних полків по 500 козаків і мало артилерію з 20 гармат. Полк ділився на два відділи, очолені осавулами. При полковникові були обозний, писар, хорунжий, сурмач, литаврник і трубач. Сотні ділилися на курені по 10-12 козаків. Плата гетьмана складала 120 злотих. Войсковий обозний і войсковий писар отримували рівну плату з полковниками. Для походу на Москву у 1618 р. гетьман П. Конашевич-Сагайдачний зібрав приблизно 20 тис. війська. В цей же період не 
ISSN 2078-6077. Наукові зошити історичного факультету Львівського університету. 2020. Випуск 21. Proceedings of History Faculty of Lviv University. 2020. Issue 21.

Іноді нереєстрові козаки числилися як джури ${ }^{35}$, вони отримували частину військової здобичі, а часом з ними ділилися і платою, відпущеною урядом на реєстр. Реєстрові і нереєстрові козаки мали однакову організаційну структуру. Козацькі вожді спочатку іменувалися отаманами ${ }^{36}$ і комовими отаманами а вже від 1574 р. стали називати себе гетьманами ${ }^{38}$ за взірцем військової верхівки Речі Посполитої. Так само за зразками Речі Посполитої були утворені уряди генеральної старшини: суддя, осавул, писар, обозний, хорунжий і бунчужний.

Спочатку військо ділилося на сотні, які називалися за прізвищем сотника. Сотні ділилися на десятки, що називалися за прізвищами десятників. 3 ростом чисельності військо стало ділитися на полки, які спочатку мали назву за прізвищем полковника. Окремі гетьмани (Г. Лобода, А. Наливайко, П. Конашевич-Сагайдачний) мали свої гетьманські полки, які називалися за їх іменем. Інші гетьмани мали свої менші підрозділи - роти чи сотні. При полковниках також були осавули, писар, хорунжий і обозний, званий отаманом. Полк складався переважно 3 п’яти сотень. На практиці це означало 500-800 козаків, не рахуючи джур-пахолків. Рідше - до тисячі козаків. Менше 500 козаків числив мало який полк ${ }^{39}$. Часом у складі полку виділялися підрозділи 3 двох-

менше 2 тис. козаків перебували у війську королевича під Вязьмою. За інформацією учасника подій полковника С. Чаплинського під Хотин у 1621 р. прийшло 30 тисяч піших і 10 тисяч кінних козаків. Реєстр війська під Хотином налічував 41520 осіб (Тарас Батюк. Козацькі збройні формування у II половині XVI - першій чверті XVII ст. Проблеми гуманітарних наук. Вип. 14. (Дрогобич, 2006), 84-93).

${ }^{35}$ Джура, від перського товариш, зброєносець, цим терміном, запозиченим з тюркської, позначалися козаки не внесені у компути (списки реєстру), які не отримували плати за службу, а лише частину військової здобичі.

${ }^{36}$ Отаман, від тюркського ота - батько і ман - людина, буквально батько-командир.

${ }^{37}$ Кошовий отаман - отаман (командир) коша (тюрк. табір). Першим відомим кошовим отаманом був Хома (Фока) Покотило, який у 1572 р. очолив морський похід. У 1574 р. на підтримку гетьмана Івана Свірговського напав 3 флотилією на Ізмаїл, Кілію і Акерман, але в гирлі Дунаю був перехоплений турецьким флотом і загинув у бою разом з своєю флотилією.

${ }^{38}$ Гетьман, від нім. hauptmann - капітан, як вищу військову посаду запровадили чеські гусити, звідки ії запозичили у польському на литовському військах. Спочатку їх призначали на час ведення кампанії, з 1503 р. ці посади стали постійними (гетьман коронний і гетьман литовський), а від 1581 р. - довічними. У 1539 р. в Польщі, а потім у Литві гетьмани отримали заступника (польний гетьман) і стали іменуватися великими. У козацькому війську згодом 3'явилися тимчасові наказні гетьмани. Польський уряд визнавав гетьманський титул вибірково, першим визнаним гетьманом був князь Богдан Ружинський (1575-1576). При кожній нагоді намагалися титул гетьмана замінити іншим, менш престижним.

39 У війську, яке у 1612-1614 рр. під командою гетьмана Андрія Наливайка перебувало на Смоленщині, підтримуючи претензії королевича Владислава на царський престол, були полки Наливайка, Бориспільця, Сидорки, Фастівця, Трохимовича та Довгаля, у яких було по п’ять сотень в кожному. Чисельність цих підрозділів була значно вищою ніж 500 козаків. Так, за оцінкою сотника Федора Бута у полках Наливайка і Сидорки разом було півтори тисячі козаків, не рахуючи пахолків-джур. У полках Трохимовича та Довгаля було по 700 козаків. У 1618 р. на московську службу перейшов полк Ждана Конші чисельністю 311 козаків. Але у його складі було тільки полковник, осавул, писар, два сотники, отаман та 305 рядових козаків, пізніше до них 
трьох сотень, очолені осавулами. Так було, наприклад, у війську гетьмана Якова Шаха і гетьмана Самійла Кішки.

Проти досконало розробленої ординської тактики нападів і збору ясиру, яку описав Боплан ${ }^{40}$ козаки протиставили доволі ефективну тактику контрборотьби. Для попередження про небезпеку зі сторони татар або турків виставлялися бікети (бекети $)^{41}$, споруджувалися редути, фirypu та використовувалися скіфські кургани (могили). Редути почали з'являтися на зламі XVI-XVII ст. під впливом французьких військових інженерів переважно на Лівобережжі. Ці польові земляні укріплення у вигляді прямокутника служили для прикриття і розміщення кінних козацьких стеж чисельністю до 50 чоловік, які чатували на можливих шляхах татарських загонів. Редути розміщалися так, щоби між ними можна було передати світловий сигнал (як правило розпалений вогонь). Для швидкої передачі сигналів про небезпеку використовувалися фігури. Вони складалися із 20 однодонних просмолених бочок, розташованих кругами по 6, 5, 4, 2 бочки. Один ряд ставився на другий, утворюючи конусоподібну фігуру. Фігури охороняли 2-3 козаки, які при появі ворога, залежно від його сили підпалювали одну або дві фігури i, таким способом, по ланцюгу давали знати про наближення противника. Широко використовувалися і скіфські кургани-могили, які перетворювали в редути і на вершині яких розміщалися дозорці та виставлялися фігури. На деяких навіть встановлювали гармати. Така система спостереження, розвідки, оповіщення і зв'язку забезпечувала козакам можливість успішно розгортати сили, щоб перехоплювати ординське військо, хоча це вдавалося не так часто, особливо в ранні періоди становлення козацтва ${ }^{42}$.

приєдналися інші козаки і чисельність полку зросла до 602 чоловік, в їх числі полковник, осавул, писар, хорунжий, отаман, 6 сотників, 51 десятник та 540 рядових козаків (Документи російських архівів з історії Украӥни. Т. 1. (Львів, 1998), 64-68, 200-218, 257-258). За пізнішим недатованим реєстром війська гетьмана Сагайдачного в складі полків налічувалося: гетьманський полк - 1560 , Михайла Дорошенка - 1450, Теморовського - 1200, Курила - 1407, Богдана Конші - 1360, Мартина Пневського - 1400, Андрія [Наливайка?] - 2330, Захариновського - 1360, Вошивого 1160 , Бонькового - 1200, Версуновського - 1430, пушкарів та візників - 451.

${ }^{40}$ Гійом Левассер де Боплан. Опис Украӥни, кількох провінцій Королівства Польського, щяо тягнуться від кордонів Московії до границь Трансільванії, разом з їхніми звичаями, способом життя і ведення воєн. (Київ, 1990), 59-63.

${ }^{41}$ Бекети, теж з тюркського, кінні стежі, які найчастіше висилалися до придніпровського та бузького лиманів із завданням спостерігати, розвідувати і оповіщати про переміщення татарських та турецьких сил і підрозділів. Служба ця була дуже небезпечною. Так, літом 1615 р. під Очаковом ординці захопили козацький бікет. Двоє полонених козаків зламалися на тортурах і видали дві козацькі стежі. Ординці підкралися до них, перебили та захопили в полон майже 500 козаків (Документи російських архівів з історії Украӥни. Т. 1, 85-86).

42 Як писав у соймовій реляції барський староста Бернард Претвич (бл. 1500-1563/1564) у 1550 р. “... у таких обставинах узграничні воєводи споряджали незаважені купи збройного люду, коней у двісті чи триста, з самих завзятих юнаків, і посилали наздоганяти орду; комонник сей гнав степами тільки вночі, яка б ні була темрява, а днював, залігши по балках, щоб не постерегли його татарські чатовники. Іноді одбивали наші в татарви здобич, іноді перепиняли ії по дорозі в узграничні осади. Звався такий похід заляганням на полі або козакуванням" (Janysz Lubomirski. Bernard Pretwicz i jego apologia na sejmie 1550 r. Biblioteka Warszawska. 1886. Lipiec). 
ISSN 2078-6077. Наукові зошити історичного факультету Львівського університету. 2020. Випуск 21. Proceedings of History Faculty of Lviv University. 2020. Issue 21.

На Низу Дніпра на о. Томаківка в середині XVI ст. з'явилося перше чисто козацьке укріплення - Січ ${ }^{43}$. Томаківську Січ зруйновали ординці в 1593 p. Ïї укріплення мали форму правильного прямокутника, висота валу сягала 1,6 м., ширина в основі - 11 м. Вал був прикритий ровом. Описи Томаківської Січі не збереглися. Князь Дмитро Вишневецький-Байда у 1554 р. збудував укріплення на о. Хортиця, які здобули ординці в 1557 р. Нову Січ козаки заложили на о. Базавлук в гирлі річок Чортомлика, Підпільної і Скарбної ${ }^{44}$. Більшість козаків збиралася на Січ тільки влітку. Домовиті козаки мали свої господарства, так звані зимівники - укріплені хутори або садиби по прикордонних містах. На зиму на Січі залишалося невелике число бездомних козаків, так званої голоти, переважно вихідців з інших станів. Хоча літом козаки займалися рибальством, полюванням, бджільництвом, скотарством та іншими промислами (зокрема видобутком солі та селітри), запастися на зиму достатньою кількістю харчів було проблематично. Запорозька кухня була доволі бідною (знаменитий куліш проста каша, солонина, сушене м'ясо та сушена риба). Козаки брали активну участь у торгівлі з Кримом, яка не припинялася, попри на постійні сутички. Свою військову здобич вони спускали торговцям з передмістя Січі, а виручені кошти - вкладали в свої господарства або витрачали в тих же прикордонних містах. Домовиті козаки мали родини, а в своїх господарствах використовували найману працю. На Січі склалася своя система управління на чолі з кошовими отаманами, які не завжди підтримували гетьманів на уряд.

Умови Дикого поля та суперництво переважно 3 ординцями 3 їх легким озброєнням призвели до зменшення та майже повної відмови від захисного озброєння. При цьому козацьке військо за рахунок високого рівня вишколу i оснащення вогнепальною зброєю не уступало також турецькому, московському чи молдовському війську. Зрозуміло, що за наявності важкої кінноти у противника доводилося діяти переважно під захистом ватенбурлу (укріплення з обозних повозок) чи польових укріплень. Легка козацька кіннота не могла протистояти важкій панцирній кінноті, зокрема польським крилатим гусарам. В окремих випадках, коли на боці противника була значна перевага в артилерії, як, наприклад, при Солониці 16-28 травня 1596 р., де майже 8 тис. козаків не встояли перед 2,5 тис. війська (переважно важкої кавалерії) польного гетьмана Станіслава Жолкєвського, який підтягнув важку артилерію, це завершувалося поразками.

\footnotetext{
${ }^{43}$ Уперше козацька Томаківка згадана під 1552 р., укріплення, схоже, з’явилося дещо пізніше y 1558 p.

${ }^{44}$ Напроти теперішнього с. Капулівка Нікопольського р-ну Дніпропетровської обл., імперський дипломат Еріх Ляссота, який відвідав Базавлуцьку Січ у 1594 р., залишив їі опис. Січ була укріплена валом з ровом, на валу були встановлені вежі та палісади, на вежах були гармати. Всередині, навколо площі розміщалися церква, адміністративні будови (в т. ч. січова школа) та курені (австрієць застав ще недобудовані курені з хмизу, накриті від дощу шкірами). Тоді на Січі були тільки 7 куренів (Пашківський, Титарівський, Дерев'янківський, Поповичівський, Іванівський, Канівський і Дядьківський). Згодом число їх зросло до 38 , а будівлі стали дерев'яними. На початку XVII ст. 3'явилися господарські будови: пушкарня, пекарня. Виросло велике передмістя з майстернями ремісників, шинками, а також двором для післанців.
} 
ISSN 2078-6077. Наукові зошити історичного факультету Львівського університету. 2020. Випуск 21. Proceedings of History Faculty of Lviv University. 2020. Issue 21.

В польових укріпленнях під Хотином (4-29 вересня 1621 р.), маючи достатню артилерію і польсько-литовську важку кінноту, козацька піхота зарекомендувала себе якнайкраще. Це ж саме стосується участі козаків у Тридцятирічній війні у складі імперської та французької армії. У битві при Білій Горі 8 листопада 1620 p., перебуваючи на правому крилі імперського війська в складі корпусу фельдмаршала Й. Ц. Тіллі (1559-1632), 400 козаків-мушкетерів в результаті потужних випалів (залпів) відігнали 2 тис. гусарів протестантського війська. При цьому козацькі мушкетери були надійно захищені німецькою важкою кавалерією. Це ж саме відбувалося і під Дюнкерком ${ }^{45}$.

Феномен українського козацтва виходить далеко за рамки східноевропейського фронтиру. 3 однієї сторони протистояння мусульманського і християнського світів, підігріте агресивною зовнішньою політикою Османської

45 Володимир Антонович. История малорусского казачества. (Киев, 1882); Дмитро Яворницький. Історія запорізьких козаків. Т. 1. (Львів, 1990), 58-125, 156-168, 173-180, 264280; Михайло Грушевський. Гетьман Богданко. Записки НТШ. Т. 16. (Львів, 1897), 1-18; Його ж. Козаки в 1470-х рр. Там само. Т. 56. (Львів, 1903), 1-6; Його ж. Історія України-Руси. Т. 7. (Київ-Львів, 1909), 21-41, 66-252, 280-304; 314-387; Степан Рудницький. Козацько-польська війна р. 1625. Записки НТШ. Т. 17. (Львів, 1897), 1-42; Його ж. Українські козаки в 1625-30 pр. Там само. Т. 31-32. (Львів, 1899), 1-76; Олег Целевич. Участь козаків у Смоленській війні 1633-4 pp. Записки НТШ. Т. 28. (Львів, 1899), 1-72; Володимир Доманицький. Козаччина на переломі XVI-XVII століть (1591-1603). Записки НТШ. Т. 60. (Львів, 1904), 1-32; Т. 61. (Львів, 1904), 33-64; Т. 62. (Львів, 1904), 65-113; Т. 63. (Львів, 1905), 114-136; Т. 64. (Львів, 1905), 137-171; Ілько Борщак. Козаки Хмельницького під Дюнкирхеном (1645): по невиданих документах архівів військового міністерства й міністерства закордонних справ у Парижі. Украӥнська трибуна. (1922. 7.01); Андрей Стороженко. Стефан Баторий и днепровские казаки. (Киев, 1904); Юрій Крохмалюк. Воєнний шлях Сагайдачного на Москву 1618 р. (Стратегічно-політична студія). (Львів, 1936); Михайло Антонович. Козацьке військо у Смоленській війні. (Варшава, 1937); Його ж. Переяславська кампанія 1630 р. (Прага, 1944); Zbignew Wójcik. Dzikie Pola w ogniu. O Kozaczyznie w dawnej Rzeczypospolitej. (Warszawa, 1960); Idem. Czy Kozacy zaporoscy byli na siuibie Mazarina. Przeglad Historyczny. T. 64. Zesz. 3. (Warszawa, 1973), 575-585; Любомир Винар. Початки українського реєстрового козацтва. Український історик. (1964), № 2-3; Його ж. Козаиька Украӥна. Вибрані праиі. (Львів-Нью-Йорк-Париж, 2003), 161-171; Вадим Сидоренко. Вогнепальна зброя селянсько-козацької піхоти XVI-XVII ст. Український історичний журнал.

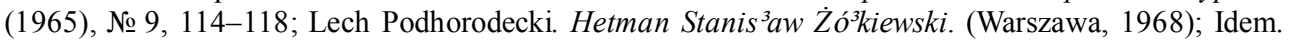
Sicz Zaporoska. (Warszawa, 1970); Лех Підгородецький, Ной Рашба. Розгром турецько-татарських полчищ (1621р.). Украӥнський історичний журнал. (1971), № 9, 131-137; Олександр Баран. Козаки на імператорській службі в роках 1635-1636. Украӥнський історик. (1979), № 1-3; Сергій Леп'явко. Козацькі війни кіния XVI cm. в Украӥні. (Чернігів, 1996); Богдан Якимович. Збройні сили України: нарис історії. (Львів, 1996); Дмитро Телегін. Часи козащькі. Січі запорозькі. (Київ, 1997); Леонтій Войтович. Військо і військова організація. Історія украӥнської культури. Т. 2. Українська культура XIII - першої половини XVII століть. (Київ, 2001), 98-104; Його ж. Козацька піхота: озброєння, організація, бойові можливості на тлі європейської лінійної піхоти кінця XV середини XVII ст. Проблеми історії країн Центральної та Східної Свропи. Вип. 4. (Кам’янецьПодільський, 2013), 64-79; Борис Черкас. Козацьке військо до середини XVII ст. Icmopiя українського козачтва. Т. 1. (Київ, 2006), 472-484; Віктор Брехуненко. Гетьман чи старший? За лаштунками номенклатури козацьких провідників (XVI-перша половина XVII ст. Наукові записки Національного університету Києво-Могилянська академія. Т. 130. Історичні науки. (Київ, 2012), 4-9; Петро Сас. Запорожиі у польсько-московській війні наприкінці смути (1617-1618 рр.). (Біла Церква, 2010), 113-260; Його ж. Хотинська війна 1621 року. (Біла Церква, 2012). 
ISSN 2078-6077. Наукові зошити історичного факультету Львівського університету. 2020. Випуск 21. Proceedings of History Faculty of Lviv University. 2020. Issue 21.

імперії혀 , з іншої сторони - ослаблення Великого князівства Литовського в умовах постійних воєн з Московським князівством, агресивна політика якого невпинно зростала ${ }^{47}$, відсутність достатніх ресурсів для оборони степового кордону i наростання релігійних протиріч всередині Польсько-Литовської держави значною мірою позначилися на формуванні цього феномену. Ситуація вимагала постійного професійного війська, утримувати яке уряд не мав ні можливості, ні бажання. Більше того релігійне протистояння, за яким вимальовувалися також етнічні протиріччя, що згодом вибухнули національною революцією, штовхали польських політиків до постійної ідеї ліквідувати саме козацтво. Залишене на самозабезпечення, користуючись підтримкою українських магнатів та прикордонної адміністрації, українське козацтво почало трансформуватися в окремий лицарський стан, який ніс на собі риси як давнього ленного лицарства (3 тою різницею, що роль ленів виконувала самочинна займанщина пусток) ${ }^{48}$, основним засобом добування ресурсів якого поступово ставала військова здобич ${ }^{49}$, найманого професійного війська ${ }^{50}$ і військових поселенців фронтиру ${ }^{51}$. 3 цих причин становлення козацтва як професійного війська затягнулося майже на століття до початку XVII ст. За цей час сформувалася ціла козацька територія з паралельною адміністрацією і фактичним козацьким контролем, який місцева

${ }^{46}$ Евгений Руссев. Борьба молдавского народа против Оттоманского ига. (Кишинев, 1968); Ярослав Дзира. Татаро-турецькі напади на Україну XIII-XVI ст. за хроніками Бельського та Стрийковського. Украӥнський історико-географічний збірник. Вип. 1. (Київ, 1971), 90-124; Владислав Хензель. Проблема ясыря в польско-турецких отношениях XVI-XVII вв. Россия, Польша и Причерноморье в XV-XVIII вв. (Москва, 1979), 147-158; Георгий Гонца. Молдавия и Османская агрессия в последней четверти XV-первой трети XVI cm. (Кишинев, 1984); Олена Русина. Україна під татарами і Литвою. (Київ, 1998); Тарас Батюк. Збройні сили України в протистоянні турецько-татарській експансії у другій половині XVI - на початку XVII ст.: історіографія проблеми. Дрогобицький краєзнавчий збірник. Вип. 10. (Дрогобич, 2006), $186-200$

${ }^{47}$ Борис Флоря. 3 історії взаємовідносин українського козацтва і російського уряду (80-90ті роки XVI ст.). Украӥнський історичний журнал. (1978), № 9, 125-129; Борис Черкас. Україна в політичному протистоянні Великого князівства Литовського з Московською державою і Кримом у 20-х роках XVI ст. Україна та Росія: проблеми політичних і соиіокультурних відносин. (Київ, 2003), 11-24;

${ }^{48}$ Олександр Моця. Українські козаки та їх рицарські аналоги в середньовічній Європі. Історія украӥнського козачтвв. Т. 1. (Київ, 2006), 143-158.

${ }^{49}$ В умовах відсутности матеріально-технічної бази і забезпечення зі сторони уряду козацьке військо могло отримувати зброю та амуніцію винятково за рахунок трофеїв та закупок, вартість яких перевищувала ресурси, які можна було накопити в козацьких землях. Це змушувало козацьку верхівку звертатися до військових походів не лише в землі Туреччини та Кримського ханства, але й у більш віддаленіші і ризикованіші каспійські та кавказькі експедиції. Торгівля військовими трофеями дозволяла вирішувати більшість питань логістики. Прикордонні старости, зацікавлені у козацькій військовій силі, ігнорували всі заборони уряду на військові поставки та торгівлю трофеями.

${ }^{50}$ Леонтій Войтович. Козацька піхота: озброєння, організація, бойові можливості на тлі європейської лінійної піхоти кінця XV - середини XVII ст. Проблеми історії країн Центральної ma Східної Європи. Збірник наукових праць. Вип. 3. (Кам’янець-Подільський, 2012), 64-79. 
державна адміністрація мусила сприймати як необхідну умову виживання i оборони власної території. Уряд не використав останньої можливости перетворити козаків у граничарів, обмежившись половинними реформами, які легалізували частину козацтва у вигляді реєстру, верхівка якого отримала шляхетство з узаконенням земельних володінь, тоді як кресові магнати отримали можливість формувати свої держави, загострюючи соціяльне становище в perioнi. Перші козацькі виступи налякали польську еліту і вона почала шукати шляхи ліквідації козацтва, при цьому продовжуючи звертатись до нього як при появі зовнішньої загрози, так і у власних авантюрах у залежних від Туреччини дунайських князівствах та Прибалтиці. У результаті після Хотинської війни у Середньому Подніпров 'ї сформувалася ціла козацька теритрія, яка охоплювала значну частину Київського, Брацлавського і Подільського воєводств, з постійним професійним військом, яке і далі утримувалася за рахунок використання неузаконеної землі, військової здобичі, захопленої під час самочинних походів в підконтрольні Туреччині землі ${ }^{52}$, найманої військової служби сусіднім володарям від правителів дунайських князівств до імператора Священної Римської імперії, московських царів і кримських принців ${ }^{53}$ та виплати реєстру, який влада намагалася скоротити, а командири розширити, зараховуючи випищикі $6^{54}$ у

\footnotetext{
51 Ярослав Дашкевич. Козацтво на Великому кордоні. Українське козацтво: сучасний стан та перспективи дослідження проблеми (матеріали для круглого столу). Український Історичний Журнал. (1990), № 12, 19-21; Сергій Леп’явко. Великий Кордон Європи як фактор формування українського козачтва. (Запоріжжя, 2001); Його ж. Аналоги українського козацтва у західному світі. Історія украӥнського козацтва. Т. 1. (Київ, 2006), 102-115; Володимир Брехуненко. Українське козацтво в колі східноєвопейських християнських козацьких спільнот. Там само, 115-143.

52 Чорне море у XVI-XVII ст. фактично було “турецьким озером”, на якому Османська імперія не тримала військового флоту, при потребі викликаючи ескадри з Мармурового або Середземного морів, а також повноцінних залог у фортецях і портах на побережжі. За таких умов навіть найбільша кримська твердиня Кафа не могла бути забезпечена від несподіваної атаки козаків (Тарас Батюк. Взяття Кафи в 1616 р. в світлі нововиявлених джерел. Проблеми гуманітарних наук. Наукові записки ДДПУ. Вип. 14. (Дрогобич, 2004), 4-15).

${ }^{53}$ Михайло Грушевський. Історія України-Руси. Т. 7. (Київ-Львів, 1909), 117-125, 147-150, 196-207; Ярослав Дашкевич. Українсько-іранські переговори напередодні Хотинської війни. Украӥнський історичний журнал. (1971), № 9, 124-131; Олександр Баран. Козаиько-перські переговори в творах Пієтро делла Валле. (Вінніпег, 1985); Любомир Винар. Козацькі зв'язки 3 Австрією і Ватиканом в 1593-1595 pр. Винар Л. Козаџька Украӥна. (Київ-Львів-Острог-НьюЙорк-Париж, 2003), 236-258; Сергій Леп'явко. Украйнське козацтво у міжнародних відносинах (1561-1591). (Чернігів, 1999); Його ж. Українське козацтво у міжнародних відносинах XVI середини XVII ст. Історія украӥнського козаитва. Т. 1. (Київ, 2006), 326-343.

${ }^{54}$ Випищики, виписні козаки - козаки, виключені з реєстру при його скороченні. Формально підлягали поверненню у попередній стан, переважно міщанський (за Вільшанською угодою 1617 р. належало виключити з реєстру “... ремісників, купців, иинкарів, війтів, бурмістрів, кафанників, балакезів, різників, кравиів та інших неприкаянних"), а навіть у посполиті. В реальності ці заходи уряду тільки підштовхували козаків до виступів і морських походів (Михайло Грушевський. Історія України-Руси. Т. 7. (Київ-Львів, 1909), 364, 392-386, 547, 550-551, 556-561; Т. 8. Ч. 1. (Київ-Львів, 1922), 118, 241-243, 275, 281-283; Сергій Лях. Випищики. Українське козачтво. (Київ-Запоріжжя, 2006), 81-82).
} 
ISSN 2078-6077. Наукові зошити історичного факультету Львівського університету. 2020. Випуск 21. Proceedings of History Faculty of Lviv University. 2020. Issue 21.

пахолки $u^{55}$ та джури ${ }^{56}$ і ділячись 3 ними частиною цієї плати. При цьому козацька територія і чисельність самого війська як і його структура та адміністрація мали постійну тенденцію зростати ${ }^{57}$.

Реально вирішити козацьку проблему у низці своїх творів (1592-1597рр. $)^{58}$ запропонував київський католицький біскуп доктор богослов'я Йосиф Верещинський (бл. 1530/1539-1598), який походив з української шляхти гербу Корчак. На думку біскупа, реорганізоване під королівською опікою козацтво мало трансформуватися у лицарську шляхетську школу. Він пропонував передати козакам територію від Запорожжя до Орші. Очолювати їх мав князь, якому підпорядковувалися козацький гетьман і 13 полків. Князь зі своїм полком мав отримати Переяслав 3 околицями. Козацький гетьман зі своїм полком мав стаціонувати у Лубнах. Інші полки мали мати свої центри у Пирятині, Старому, Борисполі, Острі, Любечі, Гомелі, Чечерську, Пропойську, Кричеві, Мстиславлі та Радомлі. Козацьке військо мало утримуватися за рахунок земельних надань і економії коштів, які уряд сплачував Кримському ханству за відмову від регулярних нападів у вигляді упоминок. Це військо мало обороняти південні кордони, які ординці постійно порушували, i, головно, служити заслоном проти агресії Московської держави. Козаків нешляхетного походження мали нобілітувати за бойові заслуги. Виглядає, що ці ідеї народилися у колі князів Ружинських і Вишневецьких. Біскуп Верещинський бачив козацьким князем

55 Пахолки або молодики - початково молоді неодружені козаки, але подібно до затяжних хоругв шляхетського війська, де пахолки складали почет повноправних войскових товаришів, отримуючи за службу тільки військову здобич, так стали називати козаків, невнесених в компути (реєстри), які служили на подібних умовах.

56 Джура - зброєносець, молодий козак, якого готували для військової служби під наглядом досвідченого козака. Термін вишколу був достатньо довгий і тривав кілька років (Дмитро Яворницький. Історія запорізьких козаків. Т. 1. (Львів, 1990), 117-118; Олександр Олійник. Запорозький зимівник. (Запорожжя, 1997).

${ }^{57}$ Михайло Грушевський. Історія Украӥни-Руси. Т. 7. (Київ-Львів, 1909), 14-42, 66-180, 253-387; Микола Андрусяк. Історія козаччини. (Мюнхен, 1950); Юрій Мицик, Сергій Плохій, Іван Стороженко. Як козаки воювали. (Дніпропетровськ, 1991); Іван Крип'якевич. Запорозьке військо. Історія українського війська (від княжих часів до 20-х років XX ст.). Вид. 4. (Львів, 1992), 133-292; Борис Черкас. Українське козацтво наприкінці XV - у першій половині XVI ст. Iсторія українського козацчтва. Т. 1. (Київ, 2006), 57-65; Його ж. Козацьке військо до середини XVII ст. Там само, 472-485; Віталій Щербак. Джерела формування українського козацтва. Там само, 65-73; Його ж. Реєстрові козаки на державній службі. Там само, 73-87; Його ж. Козацьке землеволодіння. Там само, 87-94; Валерій Смолій, Валерій Степанков. Державна ідея за козацької доби. Історія украӥнського козацтвва. Т. 1. (Київ, 2006), 227-180.

58 Твори, написані латинською мовою, як тоді було прийнято: “Дорога певна до найшвидшого і найнадійнішого осадження в Руському краї пустельних земель лицарством королівства Польського” (1592), “Оголошення про фундування лицарської школи для синів коронних в Україні, подібно до статуту мальтійських хрестоносців” (1594), “Спосіб осади Нового Києва і оборони колишньої столиці Київського князівства” (1595), “Війську Запорозькому пресвітлий виказ” (1596) та “Голос на піднесення потужної війни проти турецького царя” (1597) (Pisma polityczne. Wyd. K. Turowski. Kraków, 1858 (Poz. 6, 9, 11-12); Bibliografia Literarury PolskiejNowy Korbut. T. 3. Piœmennictwo Staropolskie. (Warszawa, 1965), 383-385). 
польського короля і великого князя литовського Сигізмунда III, для якого це було би просте розширення титулу, а князі Ружинські та Вишневецькі - когось зі свого середовища. Можливо через це Ружинські конфліктували з біскупом. Верещинський тримав свою кафедру у Фастові, демонструючи успіхи в колонізації краю і закликаючи европейських володарів до хрестового походу проти турків. Свої ідеї біскуп також поширював у листах до польських достойників, зокрема і до польного коронного гетьмана Станіслава Жолкевського ${ }^{59}$. Польська еліта не помітила цього проєкту і сама підштовхнула козацтво до епохи польськокозацьких війн, які підготували падіння самої Речі Посполитої.

\title{
EUROPEAN FRONTIER AND THE PROBLEMS OF BEGINNINGS OF THE COSSACKS
}

\author{
Leontiy VOITOVYCH \\ The Ivan Franko National University of Lviv, \\ Department of History of Middle Ages and Byzantine Studies, \\ Universótetska str., 1, 79000, Lviv, Ukraine \\ e-mail: lev67420@ukr.net
}

The problems of beginnings of the cossacks and their forming within the framework of European frontier still remain actual. Old stereotypes are slowly overcome, in particular version of appearance of the cossacks as a result of transformation of peasants-fugitives in the conditions of threat from the Horde. The weak sides of existent versions are analyzed in the offered research. The article covers a situation in steppes near the Black sea in the period of disintegration of Gold Horde and the appearance of the Crimean khanate. The appearance of cossacks from Horde, the beginnings and terms of forming of Ukrainian cossacks and are analyzed in this paper. The version of Sergij Lepjavko is fully supported in relation to forming of Ukrainian cossacks. The author also investigated the change of quantity, structure, armament, the logistic of cossack army, as well as the reason of their activity in marine hikes. Separate attention is paid to cossack elite, its relationsships with administration.

Key words: European frontier, the cossacks, Wild field, the brodnicks, Yosif Vereschinski.

\footnotetext{
${ }^{59}$ Андрей Стороженко. Иосиф Верещинский, бискуп киевский (1540-1598 гг.). Его жизнь и литературная деятельность. Сборник статей и материалов по истории Юго-Западной России. Вып. 1. (Киев, 1911), 1-171; Edward Winkler. Projekt biskupa Wereszczyńskiego regularnej armji polskiej na kresach. Przeglad powszechny. (Kraków, 1922), 120-125; Петро Сас. Йосип Верещинський. Історія Украӥни в особах IX-XVIII cm. (Київ, 1993), 169-175; Володимир Литвинов. Ренесансний гуманізм в Украӥні. Ідеї гуманізму епохи Відродження в украӥнській філософії XVпочатку XVI cm. (Київ, 2000); Тарас Чухліб. Проект "Козацького князівства" - історична альтернатива політичного устрою Гетьманщини? Український історичний журнал. (2014), № 4 (517), 71-93.
} 
ISSN 2078-6077. Наукові зошити історичного факультету Львівського університету. 2020. Випуск 21. Proceedings of History Faculty of Lviv University. 2020. Issue 21.

\section{REFERENCES}

Andrusjak Mykola. Istoria kozachchyny. Munchen, 1950. (in Ukrainian).

Antonovych Volodymyr. Istoria malorusskoho kazachestva. Kiev, 1882. (in Russian).

Antonovych Myhajlo. Kozacke vijsko u Smolenskij vijni. Varszava, 1937. (in Ukrainian).

Antonovych Myhajlo. Perejaslavska kampanija 1630 r. Praha, 1944. (in Ukrainian).

Arcybaszev Nikolaj. Povestvovanie o Rossii. Kn. 3. Moskva, 1843. (in Russian).

Archiv Jugo-Zapadnoj Rossii. Ch. 7. T. 1. Kyiv, 1887. (in Russian).

Baran Oleksandr. Kozaky na imperatorskij sluïbi v rokah 1635-1636. Ukrainskyj istoryk. 1979. № 1. (in Ukrainian).

Baran Oleksandr. Kozacko-perski perehovory v tvorah Pietro della Valle. Vinnipeg, 1985. (in Ukrainian).

Batiuk Taras. Vziattja Kafy v 1616 r. v svitli novovyjavlenyh dierel. Problemy humanitarnyh nauk. Naukovi zapyski DDPU. Vyp. 14. Drohobych, 2004. (in Ukrainian)

Batiuk Taras. Zbrojni syly Ukrainy v protystojanni turecko-tatasrskij ekspansii u druhij polovyni XVI - na pochatku XVII st.: istoriografia problemy. Drohobyckij krajeznavchyj zbirnyk. Vyp. 10. Drohobych, 2006. (in Ukrainian).

Batiuk Taras. Kozacki zbrojni formuvannja u II polovyni XVI - perszij chverti XVII st. Problemy humanitarnyh nauk. Vyp. 14. Drohobych, 2006. (in Ukrainian).

Bibliografia Literarury Polskiej - Nowy Korbut. T. 3. Piњmennictwo Staropolskie. Warszawa, 1965. (in Poland).

Bojechko Vasyl', Chaban Anatolij. Rol' zarubiïnyh terytorij v procesi genezysu kozactva. Ukrainskyj istorychnyj ïurnal. Kyiv, 1999. № 2. (in Ukrainian).

Boplan Hijom Levasser de. Opys Ukrainy, kilkoh provincij Korolivstva Polskoho, scho tjahnutsja vid kordoniv Moskovii do hranyc'Transilvanii, razom z ikhnimy zvychajamy, sposobom ̈̈yttja i vedennja wojen. Kyiv, 1990. (in Ukrainian).

Borschak Ilko. Kozaky Khmelnyckoho pid Dunkirkhenom (1645): po nevydanych dokumentakh arkhiviv vijskovoho ministerstva i ministerstva zakordonnyh sprav u Paryiii. Ukrainska trybuna. (1922. 7.01). (in Ukrainian).

Brekhunenko Viktor. Ukrainske kozactvo v koli shidnoevropejskih khrystyjanskih kozackih spilnot. Istoria ukrainskoho kozactva. T. 1. Kyiv, 2006. (in Ukrainian).

Brekhunenko Viktor. Hetman chy starszyj? Za lasztunkamy nomenklatury kozackich providnykiv (XVI - persza polovyna XVII st. Naukovi zapysky Nacionalnoho universytetu Kyevo-Mohylanska akademia. T. 130. Istoryczni nauky. Kyiv, 2012. (in Ukrainian).

Bubenok Oleh. Jasy i brodniki v stepjah Vostochnoj Evropy (VI - nachaloo XIII v.). Kiev, 1997. (in Russian).

Butkov Piotr. Ob imeni kazak. Vestnik Evropy. Moskva, 1822. (in Russian).

Celevych Oleh. Uchast' kozakiv u Smolenskij vijni 1633-4 rr. Zapyski NTSZ. T. 28. Lviv, 1899. (in Ukrainian).

Cherkas Borys. Ukraina v politycznomu protystojanni Velykoho knjazivstva Lytovskoho z Moskovskoju derïavoju i Krymom u 20-h rokah XVI st. Ukraina ta Rosija: problemy politycznych i sociokulturnyh vidnosyn. Kyiv, 2003. (in Ukrainian).

Cherkas Borys. Ukrainske kozactvo naprykici XV - u perszij polovyni XVI cт. Istoria ukrainskoho kozactva. T. 1. Kyiv, 2006. (in Ukrainian).

Cherkas Borys. Kozacke vijsko do seredyny XVII st. Istoria ukrainskoho kozactva. T. 1. Kyiv, 2006. (in Ukrainian).

Chornovol Igor. Teoria komparatyvnych frontyriv. Regionalna istoria Ukrainy. Vyp. 3. Kyiv, 2009. (in Ukrainian). 
Chornovol Igor. Vidpovidnyky poniattia frontier u inszyh mowah. Historia-Mentalnoњ»Tö̈sатоњж. Rosja i Europa Zachodnia w polskiej i ukraicskiej historiografii XIX i XX wieku. Gdacsk: Wydawnictwo Uniwersytetu Gdacskiego, 2013. (in Ukrainian).

Chornovol Igor. Komparatyvni frontyry. Svitovyj i vitczyznianyj vymir. Kyiv: Krytyka, 2015. (in Ukrainian).

Chukhlib Taras. Proekt "Kozackoho kniazivstva" - istoryczna alternatyva politycznoho ustroju Hetmanschuny? Ukrainskyj istorychnyj ïurnal. Kyiv, 2014. № 4 (517). (in Ukrainian).

Daszkevych Jaroslav. Ukrainsko-iranski perehovory naperedodni Khotynskoi vijny. Ukrainskyj istorychnyj ïurnal. Kyiv, 1971. № 9. (in Ukrainian).

Daszkevych Jaroslav. Kozactvo na Velykomu kordoni. Ukrainske kozactvo: suchasnyj stan ta perspektyvy doslidiennja problemy (materialy dla krugloho stolu). Ukrainskyj istorychnyj ïurnal. Kyiv, 1990. № 12. (in Ukrainian).

Daszkevych Jaroslav. Ukraina na Velykomu kordoni. Davnia i serednioviczna istoria Ukrainy. Na poszanu Iona Vynokura z nahody joho 70-riczcza. Kamianec'-Podilskij, 2000. (in Ukrainian).

Dokumenty rosijskih arhiviv $z$ istorii Ukrainy. T. 1. Dokumenty do istorii zaporozkoho kozactva 1613-1620 rr. Uporjadnyki L. Voitivych, L. Zaborovskij, J. Isaevych, F. Sysin, A. Turilov, B. Florja. Lviv, 1998. (in Ukrainian).

Domanyckyj Volodymyr. Kozachyzna na perelomi XVI i XVII stolit'(1591-1603). Zapyski NTSZ. T. 60. Lviv, 1904; T. 61. Lviv, 1904; T. 62. Lviv, 1904; T. 63. Lviv, 1905; T. 64. Lviv, 1905. (in Ukrainian).

Dzyra Jaroslav. Tataro-turecki napady na Ukrainu XIII-XVI st. za Chronikamy Belskoho i Stryjkovskoho. Ukrainskij istoryko-geografichnyj zbirnyk. Vyp. 1. Kyiv, 1971. (in Ukrainian).

Florja Borys. Z istorii vzajemovidnosyn ukrainskoho kozactva i rosijskoho urjadu (80-90-ti roky XVI st.). Ukrainskyj istorychnyj ïurnal. Kyiv, 1978. № 9. (in Ukrainian).

Fomenko Viktor. Pro kozacki chovny "chajky" ta "duby" (XVII-XVIII st.). Ukrainskyj istorychnyj ïurnal. Kyiv, 1968. № 8. (in Ukrainian).

Gyrka Olgierd. Biaiogryd i Kilia a wyprawa 1497 r. Warszawa, 1932. (in Poland).

Hajvoronskij Aleksej. Sozvezdie Heraev. Simferopol', 2003. (in Russian).

Hajvoronskij Aleksej. Poveliteli dvyh materikov. T. 1. Kiev-Bakhisaraj, 2007. (in Russian).

Henzel' Vladyslav. Problema jasyra v polsko-tureckih otnoszenijah XVI-XVII vv. Rossija, Pol'sza i Prichernomorje v XV-XVIII vv. Moskva, 1979. (in Russian).

Honca Georgij. Moldavia i Osmanskaja agressia v poslednej chetverti XV-pervoj treti XVI st. Kiszinev, 1984. (in Russian).

Hordeev Andrej. Istoria kazachestva. T. 1. Moskva, 1992. (in Russian).

Hraboveckyj Volodymyr, Havrylenko Vitalij. Nevidomyj universal i najdavnisza kozacka peczatka hetmana Hrygorija Lobody. Seredni viky na Ukraini. Vyp.1. Kyiv, 1971. (in Ukrainian).

Hruszevskij Myhajlo. Hetman Bohdanko. Zapyski NTSZ. T. 16. Lviv, 1897. (in Ukrainian).

Hruszevskij Myhajlo. Kozaky v 1470-h rr. Zapyski NTSZ. T. 56. Lviv, 1903. (in Ukrainian).

Hruszevskij Myhajlo. Istoria Ukrainy-Rusy. T. 5. Lviv, 1905. (in Ukrainian).

Hruszevskij Myhajlo. Istoria Ukrainy-Rusy. T. 6. Lviv, 1907. (in Ukrainian).

Hruszevskij Myhajlo. Istoria Ukrainy-Rusy. T. 7. Kyiv-Lviv, 1909. (in Ukrainian).

Hubarev Georgij. Kazaki i ih zemlja v svete novyh dannyh. Vtoraja kniha o kazakah. BuenosAjres, 1974. (in Russian). 
ISSN 2078-6077. Наукові зошити історичного факультету Львівського університету. 2020. Випуск 21. Proceedings of History Faculty of Lviv University. 2020. Issue 21.

Hulevych Vladyslav. Kazymyr Jagajlovych i Mengli Hirej: vid druziv do vorohiv. Ukrainskyj istorychnyj ïurnal. Kyiv, 2013. № 1 (508). (in Ukrainian).

Iljinskij Vadym, Szapovalov G. Zemelno-majnovyj stan na Zaporiiiii u XIV-XV st. jak chynnyk zasnuvannja kozackoho vijska nyzovoho. Muzejnyj visnyk. Vyp. 15/2. Zaporiiiia, 2015. (in Ukrainian).

Jakovlev Aleksej. Zasecznaja cherta Moskovskogo gosudarstva v XVII veke: ocherk iz istorii oborony juzmoj okrainy Moskovskogo gosudarstva. Москва, 1916. (in Russian).

Javornyckij Dmytro. Istoria zaporozkih kozakiv. T. 1. Lviv, 1990. (in Ukrainian).

Khalimonenko Hrygorij. Instytut kozactva: turkskoho I ukrainskoho. Shidnyj svit. 1993. № 1. (in Ukrainian).

Kotlar Mykola. Hto taki brodnyky (Do problemy vynyknennja ukrainskoho kozactva. Ukrainskyj istorychnyj ̈̈urnal. Kyiv, 1969. № 5 (in Ukrainian).

Krasnov Nikolaj. Kazachij flot. Vojennyj sbornik. (1885). (in Russian).

Krokhmaljuk Jurij. Vojennyj szlakh Sahajdachnoho na Moskvu 1618 r. (Strategiczno-polityczna studia. Lviv, 1936. (in Ukrainian).

Kronika Marcina Bielskiego. T. 2. Sanok, 1856. (in Poland).

Krypiakevych Ivan. Zaporozke vijsko. Istoria ukrainskoho vijska (vid kniä̈yh chasiv do 20h rokiv XX st.). Vyd. 4. Lviv, 1992. (in Ukrainian).

Lepjavko Sergij. Pro pryrodu stanovych pryvileiv ukrainskoho kozactva. Problemy ukrainskoi medievistyki. Kyiv, 1990. (in Ukrainian).

Lepjavko Sergij. Do problem stanovlennja kozackoho stanu. Druhyj Mïnarodnyj kongres ukrainistiv. Lviv, 23-28 serpnja 1993 r. Dopovidi i povidomlennja. Istoria. Ch. 1. Lviv, 1993. (in Ukrainian).

Lepjavko Sergij. Kozacki vijny kincja XVI st. v Ukraini. Chernihiv, 1996. (in Ukrainian).

Lepjavko Sergij. Ukrainske kozactvo u mï̈narodnych vidnosynach (1561-1591). Chernihiv, 1999. (in Ukrainian).

Lepjavko Sergij. Velykyj Kordon Evropy jak faktor formuvannja ukrainskoho kozactva. Zaporiiïja, 2001. (in Ukrainian).

Lepjavko Sergij. Analogy ukraiskoho kozactva u zachidnomu sviti. Istoria ukrainskoho kozactva. T. 1. Kyiv, 2006. (in Ukrainian).

Lepjavko Sergij. Ukrainske kozactvo u mï̈narodnych vidnosynach XVI - seredyny XVII st. Istoria ukrainskoho kozactva. T. 1. Kyiv, 2006. (in Ukrainian).

Ljakh Sergij. Vypyschyki. Ukrainske kozactvo. Kyiv-Zaporiïja, 2006. (in Ukrainian).

Lubavskij Matvej. Nachalnaja istoria malorusskogo kazachestva. Ïurnal Ministerstva Narodnogo Obrazovanija. 1885. № 7. (in Russian).

Lubomirski Janysz. Bernard Pretwicz i jego apologia na sejmie 1550 r. Biblioteka Warszawska. 1886. Lipiec. (in Poland).

Lvov Leonid. Otnoszenija meïdu Zaporö̈skoj Sechju i Krymom. Odessa, 1895. (in Russian).

Lytvynov Volodymyr. Renesansnyj humanizm v Ukraini. Idei humanizmu epokhy Vidrodiennja v ukrainskijfilosifii XV-poczatku XVI st. Kyiv, 2000. (in Ukrainian).

Mocja Oleksandr. Ukrainski kozaky ta ikh rycarski analohy v serednjovicznij Evropi. Istoria ukrainskoho kozactva. T. 1. Kyiv, 2006. (in Ukrainian).

Monumenta Poloniae Vaticana. T. 1. Krakyw, 1913. (in Latin).

Mycyk J., Plokhij Sergij, Storoïenko Ivan. Jak kozaky vojuvaly. Dnipropetrovsk, 1991. (in Ukrainian). 
Nikonovskaja letopis'. Ch. 3. Polnoe sobranie russkich letopisej. T. 11. Sankt-Peterburg, 1897. (in Russian).

Olijnyk Oleksandr. Zaporozkyj zymivnyk. Zaporoïja, 1997. (in Ukrainian).

Pisma polityczne. Wyd. K. Turowski. Krakyw, 1858. (in Poland).

Podhorodecki Lech. Hetman Stanisiaw Ïyikiewski. Warszawa, 1968. (in Poland).

Podhorodecki Lech. Sicz Zaporoska. Warszawa, 1970. (in Poland).

Podhorodecki Lech, Raszba Noj. Rozgrom turecko-tatarskih polczysch (1621 r.). Ukrainskyj istorychnyj ïurnal. Kyiv, 1971. № 9. (in Ukrainian).

Rohoïskij letopisec. Polnoe sobranie russkih letopisej. T. 15. Vyp. 1. Sankt-Peterburg, 1922. (in Russian).

Rudnyckij Stepan. Kozacko-polska vijna r. 1625. Zapyski NTSZ. T. 17. Lviv, 1897. (in Ukrainian).

Rudnyckij Stepan. Ukrainski kozaky w 1625-30 rr. Zapyski NTSZ. T. 31-32. Lviv, 1899. (in Ukrainian).

Rusina Olena. Ukraina pid tataramy i Lytvoju. Kyiv, 1998. (in Ukrainian).

Russev Evgenij. Borba moldavskoho naroda protiv Ottomanskoho iga. Kiszinev, 1968. (in Russian).

Russkaja voennaja sila. Istoria razvitija voennoho dela ot nachala Rusi do nastojascheho vremeni. Pod red. A. N. Petrova. T. 1. Izd. 2. Moskva, 1897. (in Russian).

Sas Petro. Iosyf Vereschynski. Istoria Ukrainy v osobah IX-XVIII st. Kyiv, 1993. (in Ukrainian).

Sas Petro. Zaporö̈ci u polsko-moskovskij vijni naprykici smuty (1617-1618 rr.). Bila Cerkva, 2010. (in Ukrainian).

Sas Petro. Khotynska vijna 1621 roku. Bila Cerkva, 2012. (in Ukrainian).

Scherbak Vitalij. Formuvannja kozackoho stanu v Ukraini. Kyiv, 1997. (in Ukrainian).

Scherbak Vitalij. Dïerela formuvannja ukrainskoho kozactva. Istoria ukrainskoho kozactva. T. 1. Kyiv, 2006. (in Ukrainian).

Scherbak Vitalij. Rejestrovi kozaky na derïavnij sluïbi. Istoria ukrainskoho kozactva. T. 1. Kyiv, 2006. (in Ukrainian).

Scherbak Vitalij. Козацьке землеволодіння. Istoria ukrainskoho kozactva. T. 1. Куiv, 2006. (in Ukrainian).

Smolij Valerij, Stepankov Valerij. Derïavna ideja za kozackoi doby. Istoria ukrainskoho kozactva. T. 1. Kyiv, 2006. (in Ukrainian).

Sopov Aleksandr. Istoriografija voprosa o proishoïdenii kazachestva. Problemy izuchenija $i$ propagandy kazachjej kultury. Majkop, 1998. (in Russian).

Sopov Aleksandr. Istoricheskie predszestvenniki kazakov, stanovlenie i razvitie kazachestva. Vestnik Adygejskoho gos. un-ta. 2006. № 1. (in Russian).

Sopov Aleksandr. Brodniki - predszestvenniki kazakov. Voprosy kazachjej istorii i kultury. Vyp. 4. Майкоп, 2009. (in Russian).

Sopov Aleksandr. Proishoïdenie kazachestva: vozvraschajas' k probleme. Vestnik Moskovskogo gos. un-ta. Seria 8. Istoria. Moskva, 2011. № 1. (in Russian).

Spieralski Zigmund. Obrona potoczna. Pamiкtnik VIII Powszechnego Zjazdu Historykyw Polskich w Krakowie 14-17 wrzerbnia 1958. Warszawa, 1958. (in Poland).

Storö̈enko Andrej. Iosif Vereschynskij, biskup kievskij (1540-1598 hh.). Jeho ïyzn'i literaturnaja dejatelnost'. Sbornik statej i materialov po iatorii Jugo-Zapadnoj Rossii. Vyp. 1. Kyiv, 1911. (in Russian).

Sydorenko Vadym. Vognepalna zbroja selansko-kozackoi pikhoty XVI-XVII st. Ukrainskyj istorychnyj ̈̈urnal. Kyiv, 1965. № 9. (in Ukrainian). 
ISSN 2078-6077. Наукові зошити історичного факультету Львівського університету. 2020. Випуск 21. Proceedings of History Faculty of Lviv University. 2020. Issue 21.

Telegin Dmytro. Chasy kozacki. Sichi zaporozki. Kyiv, 1997. (in Ukrainian).

Voitovych Leontiy. Kniazivski dynastii Shidnoi Tvropy (kinec'IX-pochatok XVI st.). Sklad, suspilna i politychna rol'. Lviv, 2000. (in Ukrainian).

Voitovych Leontiy. Vijsko i vijskova organizacja. Istoria ukrainskoi kultury. T. 2. Ukrainska kultura XIII - perszoi polovyny XVII stolit'. Kyiv, 2001. (in Ukrainian).

Voitovych Leontiy. Halycke knjazivstvo na Nyïnjomu Dunai. Halych i Halycka zemlja $v$ derïavotvorchyh procesah Ukrainy. Halych, 2008. (in Ukrainian).

Voitovych Leontiy. Halycka zemlja i Vizantia u XI-XIV stolittjah. Drohobyckyj krajeznavchyj zbirnyk. Vyp. 14-15. Drohobych, 2011. (in Ukrainian).

Voitovych Leontiy [Wojtowycz Leontiy]. Ruњ halicka a Bizancjum w XI-XIV w.: wybrane problemy. Zeszyte Naukowe Uniwersytetu Jagieiiocskiego. Prace Historyczne. T. 138. Krakyw, 2011. (in Poland).

Voitovych Leontiy. Galician Ruthenia and Byzantium in 11-13th century: selected issues. Colloquia Rusica. T. 1. Ruњ њredniowieczna a soosiedzi (IX - poiowa XIII wieku). Krakyw, 2011. (in English).

Voitovych Leontiy. Zarodiennja profesijnoho vijska. Ukraina: kulturna spadschuna, nacionalna svidomist', derïavnist'. Vyp. 21. Scripta manent. Juvilejnyj zbirnyk na poszanu Bohdana Jakymovycha. Lviv, 2012.), (in Ukrainian).

Voitovych Leontiy. Kozacka pikhota: ozbrojennja, organizacja, bojovi moïlyvosti na tli evropejskoi linijnoi pikhoty kincja XV - seredyny XVII st. Problemy istorii krain Centralnoi na Shidnoi Evropy. Zbirnyk naukovyh prac'. Vyp. 3. Kamjanec-Podilskij, 2012. (in Ukrainian).

Voitovych Leontiy. Halych u politychnomu ïytti Evropy XI-XIV stolit'. Lviv, 2015. (in Ukrainian).

Voitovych Leontiy. Jaroslav Osmomysl: sproba portreta. Ukraina: kulturna spadschuna, nacionalna svidomist', derïavnist'. Vyp. 28. Ivan Krypjakevych u rodynnij tradycii, nauci, suspilstvi. Lviv, 2016. (in Ukrainian).

Voitovych Leontiy. Osmanska imperia i Krymske khanstvo. Frontyr: moskovsko-lytovske supernyctvo, kozactvo, hranychary, hajduki. Voitovych L., Ovsinskij J. Istoria vijn $i$ vijskovoho mystectva. T. 1. Vid zachatkiv vijskovoi orhanizacji do profesijnyh najmanyh armij. Kharkiv, 2017. (in Ukrainian).

Volynkin Nikolaj. Predszestvenniki kazachectva - brodniki. Vestnik Moskovskogoo gos. unta. Serija 8. Istoria. Moskva, 1949. (in Russian).

Vynar Lubomyr. Pochatki ukrainskoho reestrovoho kozactva. Ukraiskyj istoryk. 1964. № 2-3. (in Ukrainian).

Vynar Lubomyr. Kozacka Ukraina. Vybrani praci. Lviv-Nju-Jork-Paryï, 2003. (in Ukrainian).

Winkler Edward. Projekt biskupa Wereszczycskiego regularnej armji polskiej na kresach. PrzeglNod powszechny. Krakyw, 1922. (in Poland).

Wьjcik Zbignew. Dzikie Pola wogniu: O kozaczyzni w dawniej Rzeczi Pospolitej. Warszawa, 1960. (in Poland).

Wbjcik Zbignew. Czy Kozacy zaporoscy byli na siü̈bie Mazarina. PrzeglNod Historyczny. T. 64. Zesz. 3. Warszawa, 1973. (in Poland).

Yakymovych Bohdan. Zbroini Syly Ukrainy: narys istoriyi. Lviv, 1996. (in Ukrainian).

Yakymovych Bohdan. Fenomen nashoi istoriyi. Do 500-кшсрсрнф ukrainskoho kozactva. Ukraina i ukrainci: podiyi daleki i blyzki. (Lviv, 2017). (in Ukrainian).

Zahorovskij Vladimir. Belgorodskaja cherta. Voroneï, 1969. (in Russian). 